\title{
Priapism in a patient with advanced hepatocellular carcinoma
}

\author{
Akiyoshi Kinoshita (1), ${ }^{1}$ Kazuhiko Koike, ${ }^{1}$ Masayuki Saruta ${ }^{2}$
}

${ }^{1}$ Division of Gastroenterology and Hepatology, Jikei University Daisan Hospital, Tokyo, Japan ${ }^{2}$ Division of Gastroenterology and Hepatology, Department of Internal Medicine, Jikei University School of Medicine, Tokyo, Japan

\section{Correspondence to} Dr Akiyoshi Kinoshita; aki.kino@jikei.ac.jp

Accepted 2 November 2020

\section{DESCRIPTION}

A 72-year-old man with advanced hepatocellular carcinoma (HCC) presented with priapism (figure 1) and urinary dysfunction. Three years ago, he had developed HCC in the left lobe that was $152 \mathrm{~mm}$ in diameter and undergone surgical resection. The resected specimen had shown poorly differentiated HCC with im (-), for example, FC (+), fc-inf $(-)$, sf $(+), \mathrm{Vp} 2, \mathrm{Vv} 0, \mathrm{Va} 0, \mathrm{~b} 0$ and $\mathrm{sm}(-)$. Five months later, metastasis to the left lung had been observed, and he had been treated with lenvatinib for 18 months followed by ramucirumab and sorafenib. However, after 2 months of sorafenib treatment, intrahepatic tumour progression with multiple lung and bone metastases had been observed (figure 2A). Contrast-enhanced CT of the pelvis revealed metastasis to the left pubic bone and penis with increased arterial blood flow (figure 2B,C). Angiography of the left internal pudendal artery showed tumour staining around the penis and embolisation of the left internal pudendal artery was subsequently performed; however, it was unsuccessful due to the unsuccessful embolisation of the right internal pudendal artery. Subsequently, he presented with paraparesis due to intramedullary metastasis to the thoracic spinal cord. His condition rapidly deteriorated thereafter, and he ultimately died under best supportive care, approximately 3 years after the initial diagnosis of HCC (figure 3).

Priapism is a rare urological condition, with an estimated incidence of $0.5-0.9$ cases per 100000 in the general population, and it is classified into three subtypes: ischaemic (veno-occlusive, low flow),

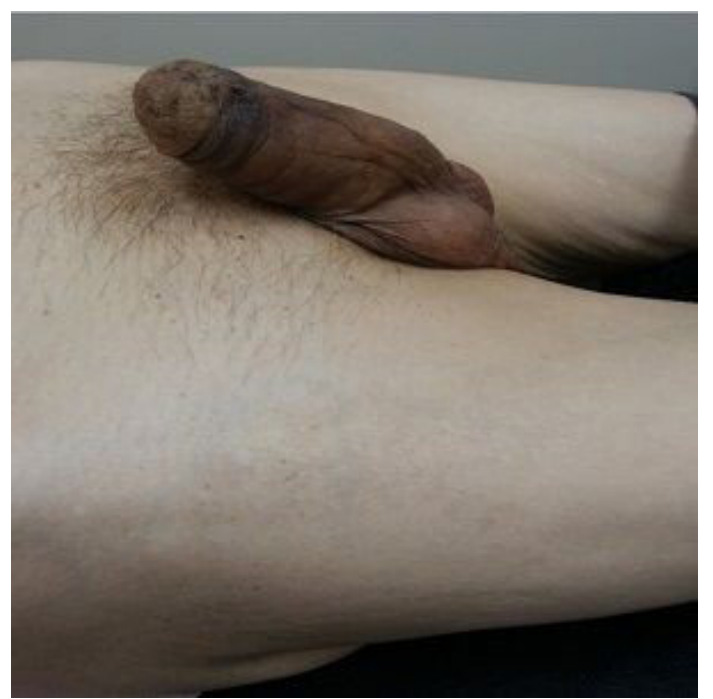

Figure 1 The finding of the patient's priapism.

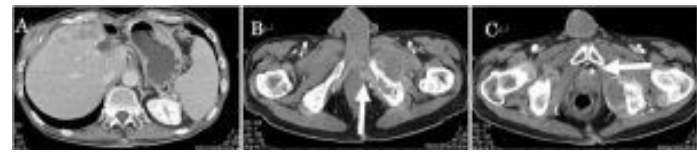

Figure 2 (A) Contrast-enhanced CT of the abdomen showed intrahepatic tumour progression with bone metastasis. ( $B$ and $C$ ) Contrast-enhanced CT of the pelvis showed metastasis to the left pubic bone and penis (arrow) with increased arterial blood flow (arrow).

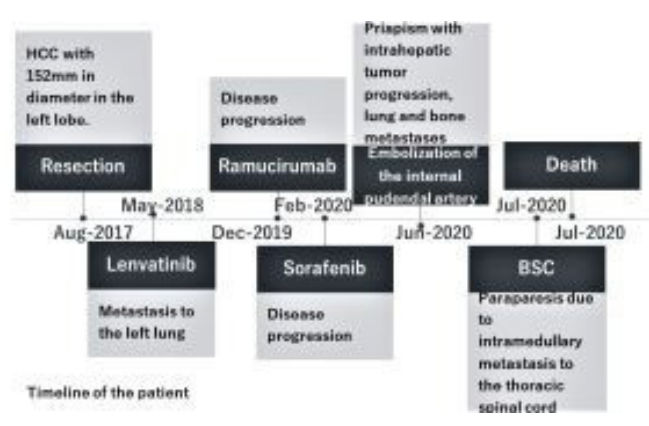

Figure 3 Timeline of the patient.

non-ischaemic (arterial, high flow) and stuttering (recurrent). ${ }^{12}$ Priapism associated with malignancy is caused by penile metastasis from other solid tumours, such as bladder, prostate, kidney, rectosigmoid, testis and lung cancer, or haematological malignancies such as chronic myeloid leukaemia, and it generally presents as ischaemic priapism. Direct neoplastic cell invasion into the penile cavernous sinuses and venous system, resulting in the complete obstruction of venous outflow is the proposed mechanism. ${ }^{2}$ Although malignancy-related nonischaemic priapism is rare, as was observed in our case, a case of non-ischaemic priapism secondary to unregulated arterial inflow without compromised venous drainage was reported in patient with metastatic bladder cancer. ${ }^{3}$ Penile metastasis from HCC with an increased arterial blood flow was considered to be the most likely cause of priapism in this

\section{Learning points}

- Priapism is a rare urological condition, which can occur in patients with malignancy. It is caused by penile metastasis from other solid tumours or haematological malignancies such as chronic myeloid leukaemia.

- Clinicians should consider the possibility of priapism in cancer patients with pelvic organ invasion. 
case. If conservative management is not successful in patients with high-flow non-ischaemic priapism, then selective embolisation of the cavernosal artery can be attempted since it has a resolution rate of $75 \% .{ }^{45}$ However, penile metastasis usually occurs in the context of more widespread disseminated cancer. Therefore, the prognosis in patients with penile metastasis is extremely poor. Furthermore, the prognosis in patients with penile metastasis from non-urological cancers and those presenting with priapism was reported to be worse than that in patients with metastasis from urological cancers and those presenting without priapism, as was consistent with our case. ${ }^{6}$

To the best of our knowledge, this is the first case of a patient with priapism accompanied by HCC. Clinicians should consider the possibility of priapism in cancer patients with pelvic organ invasion.

Contributors AK is the attending physician for this patient and drafted the manuscript. KK and MS edited the manuscript. The final version of the manuscript was approved by all authors.
Funding The authors have not declared a specific grant for this research from any funding agency in the public, commercial or not-for-profit sectors.

Competing interests None declared.

Patient consent for publication Obtained.

Provenance and peer review Not commissioned; externally peer reviewed.

ORCID iD

Akiyoshi Kinoshita http://orcid.org/0000-0002-6546-4485

\section{REFERENCES}

1 Hudnall M, Reed-Maldonado AB, Lue TF. Advances in the understanding of priapism. Trans/ Androl Urol 2017;6:199-206.

2 Ralph 0, Shroff N, Johnson MJ, et al. Malignancy: a rare, important and poorly understood cause of priapism. Sex Med Rev 2020;S2050-0521:30106-4.

3 Dubocq F, Tefilli MV, Grignon DJ, et al. Malignancy: a rare, important and poorly understood cause of priapism. Urology 1998;51:324-6.

4 Muneer A, Ralph D. Guideline of guidelines: priapism. BJU Int 2017;119:204-8.

5 Kim KR. Embolization treatment of high-flow priapism. Semin Intervent Radiol 2016;33:177-81.

6 Cocci A, Hakenberg OW, Cai T, et al. Prognosis of men with penile metastasis and malignant priapism: a systematic review. Oncotarget 2017;9:2923-30.

Copyright 2020 BMJ Publishing Group. All rights reserved. For permission to reuse any of this content visit

https://www.bmj.com/company/products-services/rights-and-licensing/permissions/

BMJ Case Report Fellows may re-use this article for personal use and teaching without any further permission.

Become a Fellow of BMJ Case Reports today and you can:

- Submit as many cases as you like

- Enjoy fast sympathetic peer review and rapid publication of accepted articles

Access all the published articles

Re-use any of the published material for personal use and teaching without further permission

\section{Customer Service}

If you have any further queries about your subscription, please contact our customer services team on +44 (0) 2071111105 or via email at support@bmj.com.

Visit casereports.bmj.com for more articles like this and to become a Fellow 